\title{
Branding Places: Developing a Sensorial Brand Identity Model: An Abstract
}

\author{
T. C. Melewar, Clarinda Rodrigues, and Charles Dennis
}

\begin{abstract}
Ambiances are created and experienced as a product of different and unique blends of sights, sounds, smells, tastes, textures and thermal conditions that resonate with our individual and collective memory (Thibaud 2011). Therefore, it is interesting to stress that sensory aspects of destinations have been pointed out as significant dimensions to create positive tourist experiences (Agapito et al. 2014; Ghosh and Sarkar 2015) and thus impact on how tourists perceive places as unique and appealing on craving new and enjoyable experiences. Moreover, if a place is successful in making itself distinct and discernible, the sum of brand experiences will influence positively tourists' impressions towards the place and their intention to revisit it (Cardinale et al. 2014). Assuming that tourists are deeply attracted towards places that stimulate their senses, the question is raised on how destination brand managers should build a strong sensorial place brand identity and then brand it. Drawing on sensory marketing and brand identity theories, this paper proposes an integrative model to develop sensorial place brand identity. This novel approach to place brand identity follows a holistic approach by considering different key influencers, enactment stakeholders and residents as co-creators in the process of delivering sensory appealing place branding messages based on a strong and unique place brand identity.
\end{abstract}

References Available Upon Request

T. C. Melewar $(\bowtie) \cdot$ C. Dennis

Middlesex University London, London, UK

e-mail: t.c.melewar@mdx.ac.uk; c.dennis@mdx.ac.uk

C. Rodrigues

Linnaeus University, Kalmar, Sweden

e-mail: clarinda.rodrigues@lnu.se 